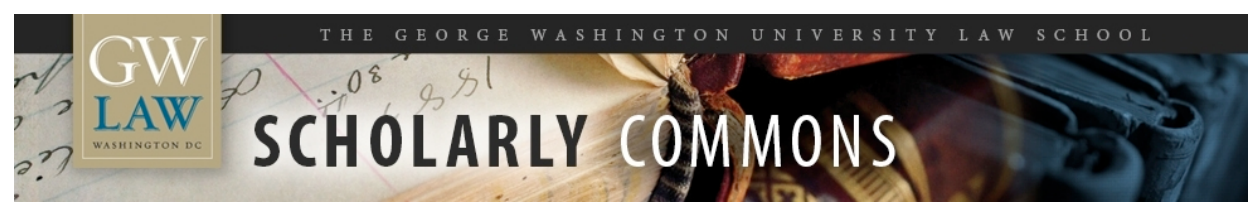

\title{
A Delicate Task: Balancing the Rights of Children and Mothers in Parental Termination Proceedings
}

\section{Catherine J. Ross}

George Washington University Law School, cross@law.gwu.edu

Follow this and additional works at: https://scholarship.law.gwu.edu/faculty_publications

Part of the Law Commons

\section{Recommended Citation}

Catherine J. Ross, A Delicate Task: Balancing the Rights of Children and Mothers in Parental Termination Proceedings in STUDIES IN LAW, POLITICS AND SOCIETY (Austin Sarat and Patricia Ewick, eds., Elsevier, 2004).

This Article is brought to you for free and open access by the Faculty Scholarship at Scholarly Commons. It has been accepted for inclusion in GW Law Faculty Publications \& Other Works by an authorized administrator of Scholarly Commons. For more information, please contact spagel@law.gwu.edu. 


\title{
A DELICATE TASK: BALANCING THE RIGHTS OF CHILDREN AND MOTHERS IN PARENTAL TERMINATION PROCEEDINGS
}

\section{Catherine J. Ross}

\begin{abstract}
This article considers the independent liberty interests of children in foster care and their mothers in parental termination proceedings. Recent federal reforms impose a mandatory deadline for the state to terminate parental rights. That policy erroneously presumes that the passage of time alone establishes parental fault and satisfies a parent's due process rights. It also fails to protect the minority of children who assert an interest in preserving a safe relationship with mothers who are unlikely to meet the state's schedule- including many substance abusers and victims of domestic violence.
\end{abstract}

The conflicting interests that can arise among parents, children and the state are particularly pronounced when the state seeks to terminate parental rights. The resulting tensions have long been aggravated by the inability of the child welfare system to find the proper balance between two competing imperatives. The first requires the state to protect children who are the victims of serious abuse or neglect and who, it is widely understood, may suffer repeated trauma, and even death, if the state fails to intervene appropriately. The second imperative is to minimize the

Studies in Law, Politics, and Society

Studies in Law, Politics, and Society, Volume 33, 163-199

Copyright $@ 2004$ by Elsevier Ltd.

All rights of reproduction in any form reserved

ISSN:1059-4337/doi:10.10161S1059-4337(04)33005-X 
psychological and social trauma that children often suffer when the state intervenes to remove them from the families that have failed to meet their basic needs.

Once a child is placed in foster care, the inexorable progress of the case will presumably lead to only one of two options: return to the family of origin or termination of parental rights followed by permanent placement in another family. Thus, from the time a child enters foster care the potential exists for the interests of child and parent to diverge dramatically. The conflicting interests of child and parent are often transparent from the day the case file is opened. In other instances, however, where the state plans simultaneously for reunification or termination of parental rights, the conflicting interests of child and parent are balanced against their potential mutual interests as the case progresses.

No one disputes that the stakes in parental termination cases are high. Every current member of the Supreme Court agrees that "[flew consequences of judicial action are so grave as the severance of natural family ties" (M.L.B. v. S.L.J., 1996, p. 119). Although the cases before the Court have focused primarily on the legal significance and emotional devastation of termination for parents, separation from a parent is at least as grievous and traumatic for the children involved (Bowlby, 1969a. b; Goldstein et al., 1996). However, the interest that a child may have in preserving a relationship with a neglectful parent has received short shrift in the wake of recent federal reforms intended to ensure permanent placements for all children within a short time after their entry into the foster care system.

Modern rights theory recognizes that minors may have legal claims independent of their parents that extend beyond their need for nurturance as members of an intimate association of family members. The Adoption and Safe Families Act of 1997 (ASFA) states "explicitly for the first time in Federal law that a child's health and safety must be the paramount consideration when any decision is made regarding a child in the Nation's child welfare system." (Strengthening Abuse and Neglect Courts Act of 2000) In doing so, ASFA places the potential conflicts of interest between children and their parents (in most instances their mothers) in stark relief. ASFA makes permanency "in a safe and stable home, whether it be returning home, adoption, legal guardianship, or another permanent placement" the goal for all of the children who enter foster care (Executive Memorandum. 1996). In keeping with its laudatory goal of moving children quickly out of the child welfare system to some form of stability, ASFA imposed an innovative federal time line, intended to insure that no child lingered in foster care for a period of years. By making the child's safety and development the priority. ASFA weighs the child's security more heavily than the mother's emotional needs and legal rights.

Looking at ASFA from the perspective of children's rights, it is hard to see any drawbacks to ASFA's categorical approach as applied to the bright line cases. Like ASFA, this paper is not concerned with the life circumstances that may have led the "abusive" mother to her predicament or her actions. (In using the term "abusive," I refer to the abusers whose label raises no questions - those who torture, drown, or 
fail even to note that a child has disappeared.) This article is instead concerned with those cases that lie outside bright-line labels and examines a paradox at the heart of recent efforts to improve the child welfare system: in their zeal to focus on the child in parental termination hearings, lawmakers imposed a categorical formula that unwittingly harms some children and mothers who are labeled "unfit" because of neglect.

In the cases at the margins, those involving mothers who may or may not be neglectful, or who are victims in their own right, ASFA's categorical treatment of mothers and children may not serve all children equally well. Unfortunately, the marginal cases are not rare (American Bar Association, 1993). In this paper, I aim to highlight a dilemma central to the child welfare system: it may not be possible to devise a legal principle that equitably addresses the interests of all neglected children and their mothers. Attempts to impose such a categorical legal principle to neglect cases may result in less than optimal solutions for some individual children and mothers, and even instances of flagrant injustice to one or both. On the other hand, it is incumbent upon the law, and on its theorists as well as its practitioners, to grapple with the hardest issues. Perhaps no issue is more difficult than the impact of the passage of time on the respective claims of a parent, a child and the state in the child welfare system.

Section 1 of this essay reviews the separate rights claims of parents and children. Section 2 analyzes the key reform of ASFA, which provides that parental rights be terminated after a child has remained in foster care for 15 out of the preceding 22 months. In doing so, I consider the conflicting interests of the child, the mother and the state, asking whether the passage of time alone is ever sufficient justification for terminating parental rights in light of the protections the law affords parents. Section 3 draws on feminist theory in considering the vital liberty interests and practical needs of mothers and children in two categories of hard cases: (1) cases involving substance abusing mothers; and (2) cases involving battered mothers whose children were removed despite the mother's success in protecting the child from observing or experiencing violence. Both of these categories illustrate that, in some instances, children's interests might be better served by flexibility where the child asserts a claim to a continued relationship with a biological parent.

\section{RIGHTS PERSPECTIVES: PARENTAL LIBERTY INTERESTS, DUE PROCESS RIGHTS AND THE RIGHTS OF THE CHILD}

The vast majority of children live with their mothers, whether in single parent households, with their father as well as their mother, or with their mother and her significant other (Fields, 2001; Fields \& Casper, 2001). This necessarily means that where abuse or neglect takes place a mother's role is likely to be at issue, either as a 
perpetrator, for placing the child in harm's way, or for failure to protect the child from another adult. Indeed, when we talk about child abuse and neglect we are almost always talking, at some level, about mothers and their children, even if the mother's partner is the abuser.

This section first considers the constitutional rights accorded to parents, regardless of sex, and the ways in which those rights diminish the independent claims of children. It then offers a way of thinking about children's legal claims within the child welfare system separate from those of their parents, with particular emphasis on the legal regime created by ASFA.

The constitutional rights of parents frequently subsume the legal rights of their children. The Supreme Court has found a substantive liberty interest in parenting, which "does not evaporate simply because [the parents] have not been model parents or have lost temporarily the custody of their child to the State. Even when blood relationships are strained, parents retain a vital interest in preventing the irretrievable destruction of their family life" (Santosky v. Kramer, 1982, p. 753). The resulting legal presumption that parents speak for their children does not fully evaporate once the children come to attention of a child welfare agency, or even once a child enters foster care. Under this legal regime, as opposed to a therapeutic one, information must be considered in a certain order. Before a court can assume that the child or someone else claiming to speak for the child (such as the state or an appointed guardian ad litem) is in a better position than the parent to present the child's best interests to the court, the court must determine that the parent has behaved in a way that justifies stripping the parent of her presumed identity of interests with her child. Only after such a finding may a court determine that the parent no longer speaks for this particular child. Consequently, any legislative initiative designed to elevate the child's developmental needs over the rights of his or her parents may conflict with generally applicable constitutional principles protecting the family unit as a whole. It is critical, therefore, to understand the scope and strength of the parent's rights before seeking to explicate the balance of interests between children and their parents in the context of the child welfare system.

The substantive due process jurisprudence that governs claims involving a parent's liberty interest in his or her child protects parents from government intervention absent a high threshold (Troxel v. Granville, 2000). In short, any infringement on the parent's rights must be narrowly tailored to serve a compelling state interest (In re H. G., 2001). But while the government's compelling interest in safeguarding children is rarely questioned, the means the government uses to achieve its goals are frequently the subject of litigation (Ross, 2000).

The liberty interest of parents in their children also mandates procedural protections before a parent's rights may be terminated. In Stanley v. Illinois (1972) the Supreme Court held that a state may not deprive a parent of his or her parental rights without an individualized determination of the parent's fitness. Speed and efficiency, the Court declared, may not be allowed to run "roughshod over the 
important interests of both parent and child" (p. 657). In subsequent cases the Supreme Court examined three procedural issues that arise in termination cases: the right to appointed counsel, the standard of proof, and the right to an appeal.

In Lassiter v. Department of Social Services (1981) the Court held that due process does not require appointment of counsel for parents in all termination proceedings. The Lassiter opinion makes clear, however, that an appellate court may reverse a trial court's decision not to appoint counsel if the decision violates fundamental fairness under the facts of the case. In addition, although the Court found that appointing counsel is not constitutionally required in all termination cases, the majority noted that a "wise public policy" would require appointing counsel for parents who cannot afford attorneys at all stages of dependency proceedings. At the time Lassiter was decided, the Court noted that thirty-three states and the District of Columbia provided appointed counsel for indigent parents in termination proceedings, and that nothing suggested that such statutes were other than "enlightened and wise." Since then, "there have been substantial dynamic statutory and procedural developments" regarding the right to counsel in termination proceedings. As of 2002, the Supreme Court of Delaware noted that Delaware was one of only five states that had not "established a right for indigent parents to be represented by counsel at State expense in dependency and neglect proceedings.... [either by statute] or as a matter of state constitutional law" (Brown v. Division of Family Services, 2002).

The Supreme Court has ruminated on the high personal stakes that make termination of parental rights something more than an "ordinary civil action" resulting in mere loss of money" (Santosky v. Kramer, 1982. pp. 747. 756). In Santosky v. Kramer (1982), the Supreme Court held that in light of the stakes in termination proceedings, due process requires that the state support its allegations by an elevated evidentiary standard — " "at least clear and convincing evidence" — before it may "sever completely and irrevocably the rights of parents in their natural child" (pp. 747-748).

Most recently, in M. L. B. v. S. L. J. (1996), the Supreme Court held that the due process and equal protection clauses mandate that a state may not deny appellate review to a person whose parental rights have been terminated. The Court held that states must provide every parent with access to the appellate courts following termination of parental rights regardless of the parent's ability to pay the requisite costs. In considering the procedures due in a contested step-parent adoption, the M. L. B. majority again focused on the substantial and irreparable injury to parents who lose all rights to their children, as well as the potential for judicial error, in holding that "decrees forever terminating parental rights" fall into "the category of cases in which the State may not bolt the door to equal justice"” (p. 124). The Court, however, did not balance the child's potential interests against the parent's rights, and did not have before it the argument that delay - whether caused by the appellate process or by other contingencies — unjustly prolongs the child's uncertainty about her fate. 
The cases from Lassiter through $M . L$. B. establish the parameters of the rights and presumptions that parents bring to termination proceedings. These constitutional protections for parents are critical, especially since the fact-finding stage of a termination proceeding "pits the state directly against the parents" (Santosky $v$. Kramer, 1982, p. 759). At this stage, the trial court's task is limited to determining whether "the natural parents are at fault." This finding of "fault" is understood to be a prerequisite for the conclusion that these particular "parents are unfit to raise their own children." Because it is assumed that children are generally best served by remaining with their parents, and a finding of fault could lead to their permanent removal from their parents' care, courts presume that the interests of children converge with the interests of parents at legal proceedings. This presumption remains, even where the facts appear to clearly rebut it (Ross, 1996). In Santosky, for example, the parents' interests were viewed as converging with their children's despite the fact that one boy, who had been removed from his parents when he was only three days old, was seven when the case was argued and had never lived with his parents. Yet even on those facts, the Court preserved the legal fiction that parents and child speak with one voice, insisting "until the State proves parental unfitness, the child and his parents share a vital interest in preventing erroneous termination of their natural relationship"; only after the State proves parental unfitness, are the interests of parent and child deemed to "diverge" (Santosky v. Kramer, 1982, p. 760).

The Supreme Court has expressed doubts about whether "the State constitutionally could terminate a parent's rights without showing parental unfitness," although it has never directly confronted the question (Santosky, 1982, p. 760). In obiter dicta, the Court opined that

[w] have little doubt that the Due Process Clause would be offended '[if] a State were to attempt to force the breakup of a natural family, over the objections of the parents and their children, without some showing of unfitness and for the sole reason that to do so was thought to be in the children's best interest' (Quilloin v. Walcott, 1978, p. 255).

Notwithstanding the due process protections accorded the liberty interest of biological parents in their children, once a child enters foster care the parental rights and responsibilities for that child are apportioned among biological parent, foster parent and the state. The manner of this division resembles nothing so much as the proverbial bundle of sticks well known in introductory law school property classes reminding us of the long common law history of treating children as property. The bundle of sticks analogy clarifies the notion that the rights associated with ownership of property can be "unbundled or disaggregated." If the property is a bundle of sticks, the owner may give away one or more sticks while retaining the balance of the bundle. The sticks may represent temporary interests such as a particular usage or a term of years. As one commentator explains, a "particular piece of property may have multiple owners of different sticks in the bundle of rights that comprises full ownership. When we are asked to determine who owns a particular stick in the 
bundle, it may not help us to know who the 'owner' of the land is because ownership of various sticks in the bundle may be spread among several people" (Singer, 2001, pp. 2-3). Similarly, no matter how long a child remains in foster care, he or she continues to "belong" to the natural parent in some respects. That natural parent - although stripped of custody and day-to-day decision making once a child enters foster care - retains the sole ability to make decisions regarding surgery and the right to marry or enlist in the armed forces as a minor, among other decisions, and is presumed to represent the child's legal interests, retaining what amounts to a future interest in the child (Smith v. Organization of Foster Families for Equality and Reform (OFFER), 1977).

The Supreme Court made it clear in Santosky that there is no room at the factfinding stage of a termination proceeding to weigh either the child's independent interest or the child's relationship with a foster family against the rights of the natural parents in the care, custody and nurture of their child. The focus during factfinding at a termination proceeding is "emphatically" not on the child, or the other opportunities open to the child, but only on whether "the natural parents are at fault" as the state alleges (Smith v. OFFER, 1977, p. 759). Even when the child demonstrates disinterest in the natural parents or positive attachment to current caregivers such as foster parents there is no room for the child's perspective until the court turns to disposition. Some commentators have criticized this legal regime for blocking a judge's ability to consider the child's need for protection and safety outside the context of parental fault (Bartholet, 1999; Gelles \& Schwartz, 1999).

Similarly, lower courts have expressly held that while the best interests of the child should be paramount in all proceedings to terminate parental rights, "a court may not base termination of parental rights solely on the best interests of a child" (In re Welfare of M. H., 1999, p. 228; Meyer, 1999). In order to terminate parental rights, a court must first find that at least one statutory ground for termination exists. Consistent with the discussion in Santosky, state laws governing termination provide for a bifurcated analysis. First, the court must ask whether sufficient statutory grounds have been shown for terminating the parent's rights (with due consideration to the parent's constitutional rights). Only then may the court reach the second question: whether termination of parental rights in fact serves the child's best interest (e.g. Minn. Stat., 2003). If the statutory grounds for termination have been well framed and the evidence that those grounds have been met is clear and convincing, the child's best interests will normally be served by termination, particularly if the state has already identified a permanent or adoptive home for the child.

In a hypothetical regime in which the child's rights were weighed heavily, fewer children would be needlessly separated from their parents either temporarily or permanently. Fewer would be removed from borderline domestic situations, and fewer of those removed would spend fifteen months or more in foster care or fail to ever find a new permanent home. In that hypothetical regime, children's attachments would also weigh in the decision to terminate parental rights. But in the 
real world, things are not so simple.

Young children are not autonomous persons. The law recognizes that children need adults to nurture and supervise them (Minow, 1990; Woodhouse, 1993). The parental rights doctrine is premised in part on this notion, and the child welfare system is in turn based upon the view that if the biological parents prove unfit for the job of raising their children, the state has a compelling interest in replacing the failed parent with one who is up to the challenge. The state's interest in the healthy development of its youngest citizens is deemed to allow the state to substitute itself and its representatives as the anointed spokespersons for the children in lieu of unfit biological parents. Children's rights advocates emphasize the importance of being able to distinguish when a child's interests converge with the parent's, and when it is imperative to recognize that the needs or interests of parent and child substantially diverge (Ross, 1996, 1999a, b). In the context of the child welfare system, it may be inappropriate to assume that the child's needs are fully represented by the parent's legal claims. At the same time, it oversimplifies matters to presume that the interests of a child in foster care are irretrievably at odds with those of his or her parents. Instead, to do justice to the potentially competing claims of mothers and children in the child welfare system, we need to struggle to find a way to hear the voice of the individual child. While the voices of children of various ages may be treated differently because the balance of dependency and autonomy shifts during the process of maturation, even very young children may have ways of communicating about their needs (Ross, 1999a, b).

However, once the law has assigned the designation of "parent $\sim$ to a particular adult, parental rights doctrine as interpreted by Santosky dictates that the child has no voice separate from the parent in court until grounds for termination are established. Because of the importance of parental rights doctrine, courts will not normally substitute the child's best interest for an analysis of parental fault. Courts frequently decline to weigh the unique circumstances of a child's life, even where they suggest that the child's emotional well-being would be served by taking into consideration factors other than parental fault, such as the child's attachment to caretakers.

This was the issue in the case of "Baby Jessica" DeBoer, who was wrongfully adopted at the age of 17 days, even though her father's rights had not been terminated. She was two years old and had known no parents other than her adoptive mother and father when Justice Stevens refused to stay the lower court's order returning her to her natural parents (DeBoer v. DeBoer, 1993). Justice Stevens explained that no law "authorizes unrelated persons to retain custody of a child whose natural parents have not been found to be unfit, simply because they may be better able to provide for her" (p. 1302).

In the similar and equally controversial case of "Baby Richard," the father only discovered that Richard was alive 57 days after the birth, well after Richard had been adopted (In re Petition of Doe, 1994). Ruling that the father's rights had been terminated improperly, the Illinois Supreme Court held that courts may not consider 
the best interests of the child before determining, as a threshold matter, that parental rights should be terminated. If they could, the court opined, "few parents would be secure in the custody of their own children" (p. 183). The corollary of this principle is that every child should be secure in her parents' custody. Thus the issue in both cases, decided in the context of private adoption rather than of the child welfare system, was a profound disagreement between advocates for the children and the birth fathers over whether to define "parents" based on biology or on the child's emotional experience (Goldstein et al., 1996).

\section{THE ADOPTION AND SAFE FAMILIES ACT OF 1997}

The pendulum of child welfare reform has repeatedly swung between efforts to preserve troubled families at virtually all costs and a passion to rescue every child in need. At the height of a prevailing but oversimplified interpretation of family preservation in the mid- 1990s, about half-a-million children were in foster care because they had been "rescued" and were waiting for their parents to be rehabilitated so that they could return home. In many of these situations, the facts made clear that the faster children were unlikely ever to rejoin their biological parents. Although foster care was designed as a temporary expedient and was administered as if it were in fact temporary, increasing numbers of children were spending three years or more in foster care, many of them in a series of homes. This phenomenon became known as "foster care drift" (H. R., 1997, p. 2740). About one-third of the children in foster care would never return home. (Duquette \& Hardin, 1999). Instead, many of these children grew up in a series of foster homes and institutions, languishing for years in a child welfare system that moved at a "glacial pace" (Gordon. 1999, p. 649). At the same time, publicity focused awareness on several egregious cases of children who had been returned to their families, only to die at the hands of a parent.

Eventually, the increasingly widespread perception that the foster care system

was out of control and hurting children led to a congressional search for uniform solutions based on the child's need for safety, nurturance and permanency (Gendell, 2001). ASFA, enacted with overwhelming bipartisan support, proclaimed "two basic goals: [p]reventing children from being returned to unsafe homes, and finding safe and loving and permanent homes for children who cannot be reunited with their families" (143 Cong. Rec. H2017, 1997).

Like other child welfare reform efforts since the 1970s, ASFA drew heavily on the child development principles set forth in the influential work of Joseph Goldstein, Albert Solnit, and Anna Freud (Gordon, 1999). These principles include consideration of: (1) the child's need for parental continuity - an adult who serves as the child's "psychological parent"; (2) the importance of instilling in the child the feeling of being safe, protected and loved; and (3) the child's compressed sense of 
time and the concomitant urgency of resolution (Goldstein et al., 1996). Above all, the leading interpreters of ASFA called on those charged with applying the law to look at the foster care system "through the eyes of the child" (Duquette \& Hardin, 1999, p. 1-7).

ASFA's proponents urged careful consideration of the child's perspective because they were aware that the interests of parents and children do not always mesh (Gordon, 1999). Several members of Congress expressly stated that the balance between children's and parents' rights had to shift under ASFA. As one commentator has noted, putting children first is 'often 'difficult and painful.' It is difficult because adults do not have children's needs and cannot easily see what they are. It is painful because what is good for children may be unfair to adults" (Gordon, 1999, p. 657). Congress made clear that where it was not possible to be equally "fair" to children and their parents, ASFA requires courts to elevate the interests of the child over those of the parent.

The effort to focus on children's needs was embodied in the Act's key provision, which provides that in order to retain federal funding, the state "shall" move to terminate parental rights with the goal of adoption or another form of permanent placement in two categories of cases: (I) cases where it is apparent early on that the child cannot safely return home because of "aggravated circumstances," such as torture or a felony assault; and (2) all cases involving children who "have been in foster care under the responsibility of the State for 15 of the most recent 22 months" (the "15/22 months rule"). In legal parlance, "shall" means that the directive is mandatory. The statute provides only three exceptions to the requirement that the state initiate termination proceedings. The 15-month deadline does not apply when: (1) the child is in kinship foster care; (2) the state can demonstrate to the court a "compelling reason" why such a petition would not serve the child's best interests; or (3) the state has failed to provide the services which its own case plan "deems necessary for the safe return of the child to the child's home."

Generally, the aggravated circumstances cases are not complex in terms of either law or morality. The facts of those cases are so heinous that line-drawing should not prove difficult. In cases involving "aggravated circumstances" the parent has already put the child's life at risk. In contrast, the cases in the second group are not so straightforward. With the passage of time, termination becomes more and more likely, and the needs all children have for stability and permanence are pitted directly against the claims of their parents. ASFA establishes a presumption that, after 15 months have passed, all children are better off if their parental rights are terminated.

In many, or even most instances, ASFA's reforms promote the actual needs of the individual child. Unfortunately, the complexities of child welfare cases are not always amenable to such an easy categorical fix, as will be demonstrated in Section 3. As a result, if states consistently apply the statute as written, ASFA may unwittingly place the claims of the state in conflict with the demonstrable needs of at least some fraction of children. 
In addition to enunciating the "15/22 months" legal rule, the Act imposes specific accelerated time lines for court proceedings designed to guarantee the child a permanent placement, whether with the natural parents or somewhere else. ASFA thus requires that a court conduct a permanency hearing "no later than 12 months after the date the child is considered to have entered foster care." This section of ASFA squarely raises the question raised in Santosky and left unanswered by the Supreme Court for 35 years: is the passage of time sufficient to establish a level of parental "fault" that satisfies the due process clause for the purposes of irrevocably terminating a mother's right to her child?

The remaining sections of this article consider the interplay between the time line and the respective rights of parents and children - rights that can either be mutually reinforcing, or may stand in direct conflict.

\subsection{The Mere Passage of Time}

Federal law creates an implicit presumption that a parent who allows a child to linger in foster care for 15 months is unfit. By virtue of this assumption, in an effort to place the child's presumptive interests front and center, the Act sidestepped the essential legal question of how the state would establish legally sustainable grounds for termination in light of the court's obligation to consider the rights of the parent in their child.

By the end of 1999, every state and the District of Columbia had amended local statutes in an effort to comply generally with ASFA (U.S. Gen. Accounting Office (G.A.O.), 1999). Illinois reconciled the standard of "unfitness" with the $15 / 22$ months rule by revising its statutes to provide, in part, that a parent may be found unfit if, pursuant to a court order, "a child has been in foster care for 15 months out of any 22 month period" (750 Ill. Comp. Stat., 1998). in re H. G. (2001), the only reported case to date considering the due process implications of the 15/22 months rule, the Illinois Supreme Court overturned the section of the state's Adoption Act creating this new ground of parental unfitness based on the length of time a child has remained in foster care.

As summarized by the court, the facts of the case are not atypical. Illinois removed H. G. from her mother's custody in March of 1996 because of neglect. The state alleged that the mother had violated a protective order by allowing $H$. G. to see her father, and had grabbed H. G.'s arm on two occasions, causing it to dislocate. H. G. entered foster care. Nine months later, in December of 1996, the court placed H. $G$. in the legal custody of the state and ordered the mother to participate in a variety of services, including obtaining appropriate housing, participating in therapy, and completing parenting classes. The record offers no indication of the relationship between the mother's housing and the allegations of neglect, nor does it indicate what services, if any, the state offered the mother in any of these three areas.

In August 1998, 20 months after the trial court's dispositional order and 29 
months (or two and a half years) after H. G. was removed from her home, the state filed a petition for termination of the mother's rights. The petition alleged that the mother was unfit because she had failed either to make "reasonable efforts to correct the conditions which were the basis for removal" or to make reasonable progress toward reunification. Trial was originally scheduled for March, 1999, but seven months of continuances, some initiated by the state, followed.

In October 1999, 14 months after the state filed its petition for termination, 34 months after the original disposition order, and 43 months after H. G. entered the foster care system, the state filed an amended petition to terminate parental rights, this time adding an allegation that the mother was unfit because H. G. had been in foster care for 15 out of the preceding 22 months. Another series of continuances postponed the trial date to the end of January 2000. By its own terms, ASFA (as Illinois implemented it) failed H. G. dismally. When the termination hearing finally began, she had been in foster care for more than three years, more than the average length of time that children spent in foster care before ASFA became law.

H. G.'s mother challenged the statute on the grounds that it violated her due process and equal protection rights because it is "not narrowly tailored to achieve its manifest purpose, improperly shifts the burden of proof to a respondent parent, and improperly invites consideration of best interest issues at the fitness portion of a termination hearing\$' in violation of the holding in Santosky (In re H. G., 2001, p. 873). The trial court ruled for the mother on all three grounds, stating " $\mathrm{t}] \mathrm{he}$ problem is inherent in that this particular statute, unlike all of the other provisions for finding unfitness, relates not to conduct of a parent or an internal flaw of character or behavior or mental illness or physical infirmity, but rather the mere passage of time" (p. 868). The Illinois Supreme Court expressly rejected the state's argument that "a fit parent does not allow his or her child to languish in foster care for 15 months" (p. 871). The court correctly pointed out that the case before it "aptly illustrate[s]" that, "in many cases, the length of a child's stay in foster care has nothing to do with the parent's ability or inability to safely care for the child but, instead, is due to circumstances beyond the parent's control" (p. 872). It continued,

[because there will be many cases in which children remain in foster care for the statutory period even when their parents can properly care for them.., the presumption contained in [the statute] is not a narrowly tailored means of identifying parents who pose a danger to their children's health or safety (p. 873).

In summary, the court stated, "[wie decline to recognize that the State has a compelling interest in removing children from foster care in an expeditious fashion when that removal is achieved in an unconstitutional manner" (p. 874).

Clarity about legal standards and zealous protection of procedural rights is particularly important in termination cases because a profound imbalance of power permeates the relationship between a mother and the state. This imbalance not only dominates the day-to-day dealings of the parties, it also allows the state to play a 
large role in crafting the record that a court ultimately reviews in most, if not all, cases. As the Supreme Court has observed, because "the child is already in agency custody" in most termination proceedings "the State even has the power to shape the historical events that form the basis for termination," thus increasing the risk of erroneous fact-finding (Santosky v. Kramer, 1982, p. 763).

If the agency drags its feet and fails to provide the parent with needed resources and support, fifteen months are likely to be consumed without any discernable change in the parent's circumstances. In addition, while the mother often lacks legal representation during much, if not all of the process, the child welfare agency is represented by counsel from the inception of its relationship with the mother. Because she lacks legal representation, the mother may be intimidated, inarticulate or confused. Consequently, she may "consent" to a course of action from which it is hard to extricate herself (such as "voluntary" placement under threat of coerced removal of her children). Equally important, caseworkers keep written records of the mother's attitude, behavior and compliance, all of which can be introduced as evidence at a termination hearing. Because the caseworker has significant leeway to describe the mother as he or she sees fit in those records, the caseworker wields enormous power. In addition, it may prove difficult or impossible to correct even factual errors in the record (Lassiter v. Dep 't of Social Services, 1981) (Blackmun, J., dissenting). As one federal judge concluded, "the damage to constitutional rights is accomplished in the many months preceding the opportunity for final judicial disposition" (Nicholson v. Williams, 2002, p. 215). The mutual interests of a mother and child who should be reunited can be compromised by the state's incompetence and its control of the narrative presented to the court at the end of 15 months.

But the child is also at risk when the state simply ignores the federal requirement that it act in timely fashion. Preliminary reports suggest that many states are failing to move to terminate when a child has been in foster care for 15 out of the last 22 months (G.A.O., 2002). Even when states seek termination on the ground that too much time has passed, courts may refuse to grant the state's petition because the state has failed to set forth legally cognizable grounds. The extent of noncompliance is unknown, in large part because the federal government does not collect data on how often states use the $15 / 22$ month rule to trigger a termination proceeding. Sparse data from a handful of states suggests that the rule focuses state agencies on the passage of time, but that it has not changed agency protocol. Officials report that they fail to seek termination after 15 months as required under ASFA for a variety of reasons, including a shortage of viable permanent homes for the children. Anecdotal reports suggest that state agencies simply fail to file for termination rather than triggering one of the statutory exemptions by demonstrating to a court that "compelling reasons" exist not to seek termination.

However, the suspicion that agencies or judges may not enforce the 15/22 month rule does not diminish the urgency of the doctrinal questions presented by ASFA's mandatory time line. If states are to comply with ASFA, they will need to draft statutes that offerjudges constitutionally sound rationales for terminating a parent's 
rights after 15 months.

\subsection{Three Statutory Models}

Despite the clear risks to children that accumulate with the length of time in the child welfare system, less than one-third of all states have even attempted to craft a statutory rationale for terminating parental rights (absent other statutory grounds for termination) after a child has been in foster care for 15 of the preceding 22 months. In many states, the reference to $15 / 22$ months (or, in some instances, a shorter period) is found only in the section on definitions, or in the section on when a termination petition should be filed, and the passage of time is not addressed in the portion of the code that spells out the grounds for terminating parental rights. A handful of states do not appear to have incorporated any reference to the $15 / 22$ month period set forth in ASFA in their legal code. These include Florida, Hawaii, Michigan, North Dakota, South Dakota, and Vermont.

The states that have tackled the drafting problem so far have tended to use one of three approaches: (1) the prima facie case; ${ }^{1}$ (2) the rebuttable legal presumption or "res ipse loquitur" approach;2 and (3) the "predictive" approach, based on evaluations of future parental capacity and behavior.

The first approach (which I call the "prima facie case"), exemplified by the statute overturned in Illinois and a similar (as-yet untested) provision in South Carolina (S.C. Code Ann., 1998) makes the placement of a child in foster care for 15 out of 22 months prima facie proof of parental unfitness and thus an independent ground for termination. The surface advantage of this approach is obvious. It enables lawmakers and judges to circumvent the logjam at the heart of ASFA which is created by the conflict between two legal principles: placing the child's best interests first, on the one hand, and the constitutional imperative not to disrupt the parent-child relationship unless strict legal standards have been satisfied, on the other.

The second approach (which I call the "res ipse loquitur" approach) is similar, but allows some flexibility. Under this regime, if a child has been in foster care for 15 of the preceding 22 months, the law establishes a presumption that the best interests of the child will be served by termination of parental rights (e.g. Mont. Code Ann., 2001). This resembles the approach in tort law that under certain conditions, if one party has been injured (the child) then another party (the parent) must have been negligent, and thus blameworthy. The presumption is that remaining in foster care for 15 out of 22 months causes injury to the child and this serves as evidence of unfitness, because a fit parent would have regained custody of the child in that period of time. Whatever the initial harm to the child may have been, this formulation makes the child's continuing presence in foster care an ongoing harm attributable to the parent rather than to the state. The res ipse loquitur approach makes a useful conceptual contribution. It helps to focus the court's 
attention on the harms the child has experienced both in the parent's custody and as a consequence of the child's prolonged stay in foster care. The shift in emphasis from the rights of the parent to the needs of the child is exactly what ASFA intended.

But even though the res ipse loquitur presumption is expressly or implicitly rebuttable, it shares some of the infirmities found in the Illinois law at issue in $H$. $G$. Once the plaintiff (the child, represented by the state) has established by circumstantial evidence that reasonable persons could conclude that the injury was caused by parental negligence, the parents' defense relies on a strong showing of an alternative explanation, which the parents may not be able to establish (Keeton etal., 1984).

The third, and most promising, approach requires that the court predict the likelihood that the parent will be a fit or unfit parent for this child in the near future. The statutes that adopt a predictive approach require the court to evaluate both the extent to which the state has provided the parent with rehabilitative programs and other opportunities to meet the state's demands, and the parent's efforts to address the state's concerns while the child has been in foster care. In Connecticut, for example, the statute expressly provides a ground for termination where the child has been in the custody of the state for 15 of the 22 preceding months and

the parent of such child has been provided specific steps to take to facilitate the return of the child to the parent.., and has failed to achieve such degree of personal rehabilitation as would encourage the belief that within a reasonable time, considering the age and needs of the child, such parent could assume a responsible position in the life of the child (Conn. Gen. Stat., 2003).

The statute reins in judicial discretion by requiring that in all cases where parents oppose termination of their rights, the trial court shall make written findings regarding seven factors: (1) the services offered to the parent; (2) the extent to which the state and the parents fulfilled the terms of any applicable court order; (3) the child's significant emotional ties with the parents or any other guardian in whose care the child has been for at least twelve months; (4) the child's age; (5) the parent's efforts to address the conditions which led to the child's removal; (6) the parent's visitation with the child while the child was in out-of-home placement; and (7) the extent, if any, to which the parent's effort to maintain a relationship with the child were constrained by unreasonable acts on the part of any other person or by the parent's economic circumstances. This standard respects the parents' rights to a meaningful opportunity to regain their children. At the same time, it allows the court to take the child's sense of the passage of time into account, and to weigh it heavily against the parent's plea for more time to attempt rehabilitation. The approach is premised on the view that children cannot tolerate prolonged delay while their parents relapse into harmful behavior. As one trial court put it, "children cannot afford to spend the rest of their childhood waiting for their father and mother to also grow up" (State Dep 't of Human Resources v. A. K., 2002, p. 9).

The child's age is a particularly important factor because it affects the child's 
sense of time, as well as the depth of the relationship between the child and the biological parent and the child's memory of that relationship. The infant placed at birth will obviously have no experience with her biological mother, and may have a well-developed relationship with a foster family, while the 14-year-old may have positive feelings toward her mother, and regard the foster family as a recent intrusion. Equally important, if the state terminates the biological mother's parental rights to a 14-year-old, she is likely to become a "legal orphan," a child who is legally free for adoption but for whom the state cannot find an adoptive home (Guggenheim, 1995). Many adolescents who graduate from foster care turn to their biological families for support. If the parental rights of the biological parent have been terminated, legal services lawyers report, teenagers "often come back and say to us, "You know, I want that termination vacated because I want to have a connection with my biological family"' (Drinane, 2000, p. 444). But ASFA does not distinguish between infants and teenagers in mandating termination after 15 months.

Courts also face the limitations of the case record in determining parental "fault" and in attempting to predict whether a child can be safe with that parent in the future. According to the American Psychological Association, specific evidence of past behavior is the best basis for prediction of future behavior (Gerbasi et al., 2000). Records in termination cases are replete with evidence of past behavior on which to premise predictions of future parenting behavior. There is, however, no easy checklist that agencies and courts can rely upon in their effort to predict whether a child can be safe with his or her parents. As psychologists explain, "[e]ach case is unique, often involving complex and confusing facts, and the stakes — the safety and welfare of a child — are very high" (Freitag \& Wordes, 2001).

A modification of the predictive approach emphasizes the extent to which prediction is based on past acts for which the parent may equitably be held responsible. In Minnesota, for example, the statute provides for termination of parental rights on the grounds that the child "is neglected and in foster care" (Minn. Stat., 2003). This ground for termination applies to children who have been placed in foster care by court order, who cannot currently be returned to their parents, and "whose parents, despite the availability of needed rehabilitative services, have failed to make reasonable efforts to adjust their circumstances, condition or conduct...." The court is directed to make findings regarding how long the child has been in foster care, as well as about the parent's efforts to rehabilitate and to maintain contact with the child, and whether the state offered reasonable services to the parent. The last two factors attempt to focus the court on parental behavior while the child has been in foster care rather than on the mere passage of time.

In contrast to Minnesota's adaptation, ASFA sidesteps the relationship between the passage of 15 months in foster care and the constitutional imperative that the state must establish parental fault. In circumventing the constitutional requirement that the state prove parental unfitness by clear and convincing evidence before terminating parental rights, the law does a disservice to both parents and children. 
Children who have been in foster care for fifteen months or more, who are not likely to return home safely in the near future, and for whom a permanent home has been identified should be able to take advantage of ASFA and be legally adopted and integrated into new families. But if the state fails to come to grips with its burden to prove parental unfitness, it may wrongfully deprive parents and children of a legally protected relationship that is beneficial to the children and unwittingly subject such children to continuing uncertainty in the form of a lengthy appeals process.

In order for ASFA's 15/22 month provision to survive wider appellate scrutiny, the state (including both the child welfare and court systems) bears the onus of keeping each case on schedule in accordance with the statute's time lines and of insuring that parents receive the services they need. If the state were to accomplish these goals, any efforts to terminate parental rights in neglect cases would necessarily be based on allegations of persistent unfitness despite opportunities to change and not merely the passage of time. The burden on the state promotes the child's legal and developmental interests as well as the parent's rights because the child may not be well served by an unnecessary permanent separation from a parent whom the child regards as his or her primary caretaker.

In addition to the individual children whose unique histories indicate that they should not be severed from their parents, there are identifiable and predictable subclasses of children who should not be permanently separated from their mothers based solely on the clock running out at fifteen months. Examples of these circumstances are the focus of the next section.

\section{3. "BAD” MOTHERS: HARD CATEGORIES, HARDER CASES}

When the abusive or neglectful parent who asserts a liberty interest and the concomitant procedural protections is a mother, an additional array of issues emerges. These include problematic, essentialist definitions of "woman" and "mother" that are loaded with normative assumptions. Essentialism refers to the notion that all women share a common experience or nature, and are characterized by common attributes and that those who fail to live up to the ideal are flawed as women (Chamallas, 2003). To be a woman is to be a current, past or potential mother, regardless of individual choice or actual condition (Fineman, 1995). To be a mother is normatively to be a "good" mother, so that the adjective need not even be stated. A "mother" by default is the normative mother, a socially constructed image that encapsulates many presumptions - especially those of a woman who is middle-class, married, and a caretaker. In this view, only the unusual, deviant mother requires a prefatory adjective: "single," "working," "welfare," or "bad." In reality, as some feminist scholars have pointed out, an infinite variety of women 
and mothers exist (Murphy, 1998; Williams, 2000). Reported opinions in proceedings to terminate parental rights offer an enormous range of portraits of mothers. Women who have abused, neglected, or failed to protect their children may be single, married, cohabiting or divorced.

Despite the ease with which we can locate these mothers in the real world, for a long time feminist theory "largely ignored 'bad mothers' and their implications for child abuse" (Ashe \& Cahn, 1993, p. 76). This silence may reflect a defensive mechanism exercised by feminists in legal practice either because they are reluctant to believe that their clients had "beaten, struck, or kicked their children," or because those realities are so difficult to "understand or interpret" (Ashe \& Cahn, 1993, pp. 79, 109). Feminist scholars in turn skirted the issue because the facts did not mesh with an early feminist meta-narrative of women as victims (Woodhouse, 1999). Recently, however, feminist scholars have increasingly recognized that "women are not only victims.., they are often guilty themselves as agents who abuse children or fail to protect them" (Becker, 1995, p. 13).

Women may abuse power and fail to protect their children in two distinguishable ways (Becker, 1995). In the first, the woman herself is the agent of aggressive or passive acts that harm her children. In the second, the woman's liability stems from her failure to protect her children from abuse or neglect at the hands of third party. In this second category, feminist theory suggests the importance of clearly distinguishing the acts and omissions attributable to the mother from those of the primary source of the harm (commonly the child's father or the mother's male companion). Just as feminist scholars have highlighted the injustices wrought by the traditional legal presumption that a man and his wife were a single legal unit for purposes of spousal violence (Anderson, 2003), SO too must contemporary courts learn to distinguish when mothers can and cannot be held accountable for the actions of the men in their lives. Women who know that a particular person threatens their child's safety and nevertheless fail to protect the child from predictable or on-going harm, however, transform themselves into agents of abuse. For example, it is widely understood that the mother who refuses to leave a man who she learns is sexually abusing her daughter is not a safe custodian for that child (Appell, 1999; Venier, 2000).

The context in which events occur and individuals make decisions is frequently overlooked in child welfare decision-making even though it is transparently clear that some mothers cannot muster the resources to protect their children without help. One of the major insights of contemporary feminism is particularly apt with reference to the child welfare system: it is necessary to deconstruct the gender and class neutrality of laws in order to reveal alternative accounts of power and reality (Smart, 1989). In context, victimization and social structures contribute to the determination of which women regain their children from the child welfare system and which women lose them forever. Extreme poverty in the face of a lack of services, single parenthood and race all contribute to both initial intervention and ultimate removal of children (Pelton, 1998; Ramsey, 2003). For this reason, ASFA 
envisions preventive services that are adequate to eliminate unnecessary removals.

Current federal law retains the prevention and reunification provisions that were enacted as part of the Child Welfare Act of 1980. ASFA modifies the "reasonable efforts" provisions of the 1980 Act by providing that some small proportion of children have been hurt so badly, and some parents are so clearly incapable of transformation, that in those cases, time and resources should not be wasted on fruitless efforts that disserve children who will never go home. In order to move those children into new permanent homes more swiftly, ASFA defines the "aggravated circumstances" which eliminate the requirement that the state make "reasonable efforts" to preserve the family. In all other instances, ASFA as integrated with pre-existing laws requires that "reasonable efforts shall be made to preserve and reunify families." "Reasonable efforts" include providing services that would "prevent or eliminate the need for removing the child from the child's home," as well as services following removal "to make it possible for a child to safely return to the child's home" (Child Welfare Act of 1980).

Consistent with its vision of termination after a child has remained in foster care for 15 months, however, ASFA specifies that the state is no longer obligated to provide services to the family after the expiration of the 15 month period. By allowing the state to curtail services for the mother after a child has been in foster care for 15 months (regardless of when the mother actually began to receive the services), ASFA may exacerbate the constitutional infirmities of the 15/22 months rule as viewed from the perspective of the parent's rights. Some states do not even wait 15 months before cutting off services. Utah, for example, will not provide reunification services for more than one year for children over three years of age, and makes services available for only eight months where children under age three are involved (Utah Code Ann., 2003).

Persistent complaints about the lack of funding for preventive services support the view that poverty continues to provoke the separation of children and parents (Ramsey, 2003). The label of neglectful parent is skewed by class, race, culture and ethnicity from the point of reporting and investigation through removal and termination (Bartholet, 1999; Roberts, 2002; Ross \&Cahn, 2000). Totheextentthat child welfare agencies or courts view some mothers as neglectful based primarily on cultural differences or poverty, a family's failure to conform to an idealized notion of middle class life does not constitute a legitimate basis for removing a child.

For example, Adriana Recodo escaped from an abusive domestic relationship but had no income, no place to live and no transportation. When she sought help from a social worker, she received a referral to a psychologist and her son entered foster care. Recodo was studying for her G.E.D. and seeking employment. She could not find stable housing, but the state did not provide her with housing assistance. Her parental rights were terminated due to "chronic instability" in her employment and housing (Recodo v. State, 1997). When the Supreme Court of Nevada affirmed the termination, a pointed dissent put Recodo's case in the context of other termination 
cases that had reached the state's highest court, concluding that "the State's modus operandi appears to be to go into the homes of handicapped, powerless and usually very poor parents, remove their children.., and put the children into the home of substitute parents who are more affluent than the natural parents and more pleasing to social service agents than the natural parents" (p. 1136).

Yet the relationship between poverty and entrance into foster care should not be surprising. It is inseparable from our society's public expectations and legal norms concerning the privatization of caretaking (Fineman, 1999). The denial of collective responsibility for caretaking in favor of norms that emphasize autonomy and selfreliance deprives caretakers of the social, financial and government support that many of them desperately need (Fineman, 1998). The institution of foster care itself may be understood as a substitution of one private caretaking unit for another, albeit with a small government subsidy (Ross \& Cahn, 2000). The children of neglectful parents would benefit greatly from a more sensitive filtering system, in which neglect that does not result in serious harm or danger would trigger benefits in the form of services, rather than potentially unwarranted removal (Goldstein et al., 1997).

Poverty can also interfere with a parent's ability to reclaim children who have entered foster care. In New York City, for example, public interest lawyers report that the shortage of available apartments for low income parents means that a significant number of parents remain separated from their children solely because they lack adequate housing (Kaufman, 2004). While children are in foster care they do not count as members of their mother's household. The mother does not receive public benefits which she might otherwise get, and cannot claim that the children live with her when she applies for a larger apartment in subsidized housing. The mother finds herself in a closed system where she cannot regain her children unless she has enough space, and she cannot get enough space unless she has possession of her children.

A range of other problems common to parents whose children enter foster care, such as substance abuse, imprisonment, and domestic violence, are not amenable to speedy resolution. Under ASFA, each of these problems might form the basis for termination of a mother's rights as soon as the fifteen month period expires, even if the child could potentially be kept safe in the home with sufficient services. Some children whose mothers have such problems might be better served by preservation of the parental bond than by termination. An individualized determination of the child's best interests would weigh such factors as the child's age, the specific nature of the mother-child relationship, demonstrated harm to the child, and the identified placement alternatives. Because ASFA imposes a categorical imperative that parental rights be terminated after the passage of a certain amount of time, it does not appear to permit the exercise of judicial discretion in response to the best interests of those children who would be better off retaining a legal relationship with their mothers (G.A.O., 2002). 


\subsection{Substance Abuse}

Substance abuse is highly correlated with child neglect and abuse. When Congress adopted ASFA, it noted that, along with poverty, substance abuse is "one of the three most common reasons for children entering foster care" (H. R., 1997, p. 19). It estimated that substance abuse occurs in "up to $80 \%$ of substantiated abuse and neglect cases." Both alcohol dependency and regular use of illegal substances show a high correlation with child neglect although direct causation has not been demonstrated (Egami, 1996). The General Accounting Office reports that most children in foster care have at least one parent who abuses one or more illegal drugs such as cocaine, methamphetamnines or heroin, and most parents who use illegal substances have done so for five years or more, suggesting that they will not be readily amenable to rehabilitation (G.A.O., 1998).

The common relationship between the removal of children from their homes and a variety of biases involving race, class and other norms, noted above, may also be implicated in child welfare cases involving substance abuse (Roberts, 2002; Ross, 1 999a, b). It is, however, misguided to ignore the pernicious effects that parental substance abuse may have on children, regardless of the precise substance of choice (Bartholet, 1999). Substance abuse can alter judgment, diminish impulse control, and stimulate aggression. At the core of the problem, substance abuse may make it impossible for a parent to perceive - much less respond to - a child's needs. The inability to perceive the world around her accurately often interferes with the parent's ability to minister to the child's most basic needs. As one teenager reflected, looking back on a substance-abusing mother, "I realize that drugs were more important than me, that I didn't come first in my mother's life. She wasn't worried about if I ate or where I slept - she was more worried about drugs" (National Center on Addiction and Substance Abuse (CASA), 1999, p. 18). Another teen summarized her experience with a substance-abusing mother, saying, "She was always off doin' her own thing. She wasn't even really a mom" (CASA, 1999, p. 16).

For purposes of this discussion, it is not necessary to enter into the debate over whether substance abuse has its genesis in illness, is a rational response to stress, or results from moral failings. From the perspective of the ASFA timeline, the critical issue is that "parents are frequently ordered to undergo drug treatment or other counseling as a condition to regaining custody of a child in foster care. Given the realities of limited funding, it is not uncommon for there to be waiting lists to receive such services" (In re H. G., 2001, p. 872). Thirty-nine of the 46 states that responded to a recent federal survey reported that they lacked sufficient drug treatment programs (G.A.O., 1998). The dearth of services is even more pronounced for women than for men (H. H. 5., 1999). Social workers report that many women feel trapped - they fear that if they voluntarily enter a treatment program, they run the risk that their children will be removed from them and placed 
in foster care (CASA, 1999). Policies that result in forced separation of children from mothers who enter treatment programs run counter to research suggesting that mothers who are able to keep their children while in treatment are more likely to complete treatment successfully (Friedland, 2000).

Even where services are available, substance abusers often require several courses of treatment before they stop relapsing (and some never succeed in breaking the cycle of addiction or significantly improve their ability to function) (Denzin, 1987). From the vantage point of a mother's parental rights, this suggests that when the state removes children because of neglect stemming from a mother's substance abuse, the 15-month clock is likely to run before a mother can establish that she has successfully completed treatment. The running of the clock is of equal concern from the child's point of view if it means that the child loses the chance to have a sound relationship with a parent because timely, comprehensive treatment is not available for that parent.

The likelihood that a mother will regain custody of a child who has entered the child welfare system is further diminished if the mother is incarcerated as a result of her abuse of illegal substances. As many as $80 \%$ of incarcerated women are mothers, and most of those are single mothers (Downey, 2001). Nearly two-thirds of women in state prisons report that their children lived with them until they were incarcerated (Mumola, 2000). If a woman is in prison because of drug related offenses, the court may have been required to sentence her under mandatory sentencing guidelines without discretion to consider the impact of the sentence on her children. Such la?ws have an unintended disparate impact on mothers and fathers. When men who live with their children enter prisons, over $90 \%$ report that the children remain with the child's other parent; only $1 \%$ of children of male inmates enter foster care (Acoca \& Raeder, 1998). In stark contrast, only $28 \%$ of women prisoners report that their children are living with the children's father (Mumola, 2000). Although over half of the children of women prisoners live with grandparents or other relatives, nearly $10 \%$ of women prisoners report that their children have entered foster care - putting them at risk of termination of parental rights since the average mother in a state prison is expected to remain there for 49 months (Mumola, 2000).

If applied mechanistically, the $15 / 22$ months rule would be a death knell for the parental rights of all parents with children in foster care who remain in jail for more than a year and a half. Unfortunately, effective treatment programs for women involved with the criminal justice system are virtually non-existent. From the vantage point of the incarcerated mother who wishes to retain a relationship with her child, the state's reliance on the 15/22 months rule seems patently unfair. As one women's advocate explained, "[flor many inmates, children are a life-sustaining force. To break that bond is a punishment of the worst kind" (Acoca \& Raeder, 1999, p. 136). In order to avoid categorical severance of the parental rights of all incarcerated women, courts could perform an individualized assessment. Such an assessment could examine the mother's fault and predict her future behavior by 
looking at such factors as whether she has pursued opportunities for treatment, cooperated with and completed services that were made available, relapsed and tested positive for drugs, experienced further arrests, and whether she used every available means to maintain contact with her child (such as writing letters, calling and seeking visits). Under ASFA the incarcerated mother could permanently lose her parental rights even if she made every feasible effort to rehabilitate herself, communicate with her children or have them visit her in jail. This happened to a Nevada woman who had no substance abuse problems and had provided a stable home for her children for several years. She was serving a sentence for violating the conditions of her parole on an old conviction for forging checks, after her boyfriend turned her in to authorities for leaving the state without permission. The mother fulfilled every condition of her case plan that could be accomplished while she was in prison, maintained contact with her children and the child welfare agency, and was scheduled to be released no later than 11 months after the trial court terminated her rights. Fortunately, she was able to file an appeal, and the state's highest court restored her parental rights, which it found had been terminated "solely based 'on the passage of time' "(In the Matter of J. L. N., 2002, p. 960). Other women are also likely to find that the $15 / 22$ months have expired while they remained in prison.

Even where courts insist that the state establish a ground for termination other than the passage of time, incarceration is likely to contribute to termination under more generalized theories of fault. Appellate courts in several states have expressly held that termination may not be based solely on the parent's incarceration. In most instances, however, courts treat incarceration as a factor in determining whether the parent will be able to resume parenting obligations, looking at "factors being related to incarceration" rather than deciding to terminate parental rights based "solely" on the fact of incarceration (In re Brettany M., 2002; In re Dependency of J. $W, 1998$; in re P 0. M., 2002; In re R. P, 1993; In the Matter of J. L. N., 2002; Johnson v. Ark. Dept. of Human Services, 2002).

Commentators have largely overlooked two recent changes to the federal law, which courts are likely to erroneously view as "factors being related to incarceration" bearing on a mother's ability to resume parenting responsibility. First, as part of the Temporary Assistance for Needy Families (TANF) legislation (commonly referred to as "welfare reform"), Congress "stipulated that persons convicted of a state or federal felony offense involving the use or sale of drugs are subject to a lifetime ban on receiving cash assistance and food stamps" (Allard, 2002, p. 1). Forty-two states are enforcing the ban in full or in part and, although it applies only to benefits for the mother, it is likely to diminish the household income of paroled drug offenders significantly and result in the mother's "neglect" of children who have been returned to her.

In a second development, the federal government authorized local Public Housing Authorities to obtain criminal records and to use information about drug convictions to deny public housing to people who either have a conviction or are "suspected of drug involvement" (Allard, 2002, p. 12). This provision not only bars 
mothers convicted of drug offenses from obtaining public housing, it also means that they cannot stay with relatives in public housing without subjecting their hosts to the risk of eviction. The combined blow of a lifetime ban on welfare benefits and lack of access to public housing severely diminishes the prospect that a mother newly released from prison will be able to convince authorities that she can provide a safe home for her children. Since ASFA provides that the state does not have to engage in "reasonable efforts" after a child has been in foster care for 15 out of 22 months, the poverty often associated with a mother's status as a drug offender may be transformed into an unwarranted justification for permanently severing her from her children.

In the absence of broader social reform, however, termination because a relationship has withered while a parent is in prison fulfills ASFA's intention to require the law to look at foster care through the child's eyes. From the viewpoint of a young child, it may not matter why her mother is unable to care for her. What matters is that whatever stability she once had has been disrupted, her mother has not been her primary psychological parent and, perhaps (if she is lucky), someone else now occupies that place in her life.

Conflict between the needs of the child and the desires of the parent may be brought to a head even before termination is an issue. The mother may have a right to maintain her relationship with her child even while using drugs or incarcerated, but the child may have an equally strong claim not to have contact with a parent if such contact is more harmful than beneficial. Consider, for example, a young child in a stable, pre-adoptive foster home about whom I was consulted. He has no memory of either of his drug-addicted parents. One parent - who is still addicted to crack - has vanished, and cannot be located by the child welfare agency. The other parent, who is in prison on charges related to drugs and has not seen the child for several years, requests that the agency bring the child for a visit and the agency complies. As a result of contact with his virtually unknown parent in jail, the child experiences severe developmental setbacks. These setbacks include rage, severe enuresis, and other behavioral manifestations so pronounced that the foster parents reconsider whether they want to adopt the boy, ultimately asking the agency to remove him from their home. Meanwhile, the parent is granted parole, expects to be released shortly, and seeks custody (see also Dependency of

I. $W, 1998)$.

How should a court respond to an absent parent's demands for continued visitation and custody? The child's best interests must weigh heavily in the decision, but that is not necessarily a sufficient response to the claims of parental rights, especially if the parent has completed drug counseling and was a model prisoner. On the other hand, it is hard to imagine how a parent newly released from prison, without an apartment or a job, whose kin were not available to care for the boy when the parent was sentenced, will be able to handle the stresses of parenting a demanding child while seeking to adjust to life after prison. These conflicting priorities of mothers' rights and children's needs may be irreconcilable both as a 
matter of generally applicable law and as applied to specific cases. Congress concluded that such conflicts must be resolved in favor of the child's needs, whether or not the mother is at "fault" in the sense of intent, omission or other facts suggesting accountability as opposed to strict liability. When a court is confronted with such a choice, the child's interest outweighs the parent's claim because the legislature has made it clear that the consequences of any other decision are too harmful to the child and, ultimately, to society (In re Doe, 1994, McMorrow, J., dissenting). As the State of Washington's highest court pronounced even prior to the ASFA regime, "when the rights of parents and the welfare of their children are in conflict, the welfare of the minor children must prevail" (In re K. R., 1995, p. 146).

This child-centered view does not depend on any interpretation of mothers as good or bad, self-sacrificing or seLfish. It reflects the law's intervention as defender of those least able to protect themselves. The law presumes that adult women can rise to their own defense even if they have been victimized, but that children cannot. Even within that framework, however, the principle of balancing irreconcilable claims in favor of the child rather than the mother should not allow the law to sidestep the analytical question of how to reconcile placing children first with the liberty interests of parents, as it attempts to do under ASFA's 15/22 month rule.

In the final section of this paper I turn to a category of cases involving domestic violence, in which the independent but mutually supportive interests and liberty claims of mother and child may remain congruent in the face of the challenge the $15 / 22$ month rule poses to their ability to survive as a family.

\subsection{Battered Mothers and Their Children}

A large number of incarcerated women, presumably including some of the jailed substance abusers discussed in the previous section, have experienced domestic abuse (Cahn, 2003). But many other victims of domestic violence who have no history of drug abuse, have never been imprisoned and have neither abused nor neglected their children, the women who are the focus of this section, are also at risk of having their children removed from their care. Advocates for battered women and their children have succeeded in promoting the widespread realization that children who witness domestic violence are its victims even if the children do not suffer physical trauma themselves (ABA, 1994; Edelson, 1999). This development, however, had an unanticipated effect when it resulted in the removal of children from battered mothers who had succeeded in protecting them from witnessing any abuse, or who had successfully extricated themselves from their relationships with their abusers (Gische, 2000).

Mothers who are victims of domestic violence too often become the subjects of "double abuse," in the words of District Court Judge Jack Weinstein: first by a partner and then by the state "through forced unnecessary separation of the mothers from their children on the excuse that this sundering is necessary to protect the children" (Nicholson V. Williams, 2002, p. 163). In re Nicholson (2002), a case that 
should become a landmark, Judge Weinstein considered the claims of a class of battered mothers whose children were deemed neglected by the New York City Administration for Children's Services (the City) solely because the mother was a victim of domestic abuse. (The court also considered the claims of a court-created subclass of their children.) Judge Weinstein reflected early on that the case involved "three sometimes conflicting principles":

First, as a parent, a mother has rights to uninterrupted custody of her children and a child has rights to remain with parents; within wide limits, adults and children in a household are immune from state prying and intrusion. Second, domestic abuse - particularly if physical _of a mother or child will not be tolerated. Third, the state has the obligation to protect children from abuse, including, where clearly necessary to protect the child, the power to separate the mother and child (p. 164).

The court held that the City had violated the right of mothers and children to live together (the first principle) by misconstruing its mandate not to tolerate domestic abuse (the second principle) and by unjustifiably relying on that mandate when it misused its power to separate children from their mothers in order to protect the children from abuse (the third principle).

The ten women named as plaintiffs in Nicholson display remarkable similarities. Not one plaintiff mother had struck or physically abused her child. Indeed, the definition of the class omitted battered mothers who had abused their children or were still failing to protect their children from abusers. In each instance, one or more children were removed from a battered mother either because the batterer had also attacked the child (and the mother had "failed to protect the child"), or more commonly, because the mother either had not extricated herself from the abusive situation or, in the process of trying to separate from her abuser, entered a transitional situation that was not deemed appropriate for the child (such as no longer having an apartment to live in). In many instances, mothers included in the class had been charged with neglect or abuse based on strict liability, even though their children had not witnessed the abuse and had not suffered either physical or emotional harm in the mother's home.

The sharp parallels to the problems that ASFA's 15/22 months rule creates for mothers with histories of substance abuse, discussed above in Part 3.1, are readily apparent, including the reluctance of many mothers to seek help (even if it were available) due to fear that scrutiny will lead to removal of the children from the mother's home (Lemon, 1999). Mothers who are victims of domestic violence, however, have an even stronger argument than substance abusers that they are not "at fault," especially in light of the many obstacles to separating from an abusive situation. These obstacles include the increased physical danger to the woman and her children in the period immediately following her departure, the lack of domestic violence shelters, an inability to find permanent housing, and a lack of employment (Kintzel, 2002).

The published opinions in the case mention ASFA only once, in the context of 
the complex interacting federal, state and local statutes and regulations implicated by the issues in the case (Nicholson, 2001). The interaction of the City's treatment of abused mothers and the ASFA time line was not an issue in Nicholson, and the record does not indicate that any of the named class representatives in Nicholson suffered the termination of parental rights (perhaps in part because they were well represented once they became part of the class). But the issues of removal, passage of time, and delay are likely to mean that some proportion of mothers who are victims of domestic violence will lose their children permanently, for no other reason than that City agencies acted with "benign indifference" while the clock ran to 15 months (2002, p. 163). In an interim opinion on Nicholson, the Court of Appeals for the Second Circuit noted that a serious substantive due process question would arise if a child were removed from a "blameless" parent and asked the State's courts to determine "whether removing a child from a battered mother serves the interests of the child" (Nicholson v. Scoppetta, 2003, pp. 173-174). The matter is still pending.

In considering the Second Circuit's question, New York's highest court should acknowledge the child's independent interest in remaining with his or her mother and siblings. Under some circumstances, where the child seeks to maintain a relationship and the child's safety can be assured, the child's interest in preserving at least a legal relationship with a biological family constitutes a corollary of the mother's interest in preserving her parental rights. But ASFA ignores the child's potential claim. It imposes a legal presumption that every child who has been in foster care for 15 out of 22 months would be better off severing ties with her biological parents and moving into a new permanent situation, unless the case falls within one of the three enumerated exceptions. The statute assumes that although the natural parent may continue to speak legally for the child until the termination proceedings are completed, the state, advocating termination, more accurately represents the child's best interest, and does not provide the child with an independent voice. In many, or even most, instances, the state may indeed express the child's real interests, especially in cases involving physical abuse of the child. But ASFA leaves no discretion for taking into account that some individual children (especially those of "blameless" parents) may have a liberty interest in preserving their natural families. (The sole exception under ASFA involves older adolescents who may refuse to consent to adoption.)

The psychological and emotional detriment to a child who is separated unnecessarily from a parent (and siblings) has been well documented (Arredondo \& Edwards, 2000). The child suffers the trauma of separation, leading to such symptoms as fear, anxiety, depression, a diminished sense of self and regressive behavior. For children separated from their mothers because of domestic violence, all of the symptoms associated with loss occur at the same time that the child "confront[s] an unfamiliar and often dangerous foster care system," including the frequent pattern of separation from friends, neighborhood and school (Nicholson, 2002 , p. 253). Children frequently believe that they are responsible for the breaknp 
of the family following domestic violence just as they do in cases of divorce. The intensity of those feelings may be exaggerated where the state intercedes due to domestic violence because the child does not know whether the battered parent is safe. But experts suggest that separating a child from an abused mother may be compared "to pouring salt on an open wound" (Nicholson, 2002, p. 199). When children who are safe with their mothers experience removal as aggravating their fears, the state's claim that removal serves the child's best interests is materially undermined.

The right of a mother and child to remain together arguably does not belong to the mother alone. The Second Circuit recognized a "right to the preservation of family integrity encompassing the reciprocal rights of both parent and children a quarter of a century ago in Duchesne v. Sugarman (1977), and reiterated what it termed a "fundamental right" to "remain together" in 1999 (Tenenbaum v. Williams, p. 600). Finding a "mutual interest in an interdependent relationship," the Court of Appeals identified what it labeled "consistent support" in Supreme Court decisions concerning the rights of parents (Duchesne, 1977, p. 825). In Nicholson, Judge Weinstein expanded this doctrine by enunciating an interest in "familial integrity," which guarantees all family members a right not to be separated from each other (2002, pp. 233-234).

Supreme Court opinions skirt the issue but offer some support for the argument that the liberty interest is reciprocal. In Michael H. v. Gerald D. (1989), for example, the plurality expressly noted that the Court "never had occasion to decide whether a child has a liberty interest, symmetrical with that of her parent, in maintaining her filial relationship" and declined to do so in what it construed as a case involving a claim to preserve a child's relationships with two "fathers," one biological and the other — the mother's husband — statutory (pp. 130-131). In a compelling dissent Justice Brennan went a step further. He recognized that the relationship between the biological father and his child constituted "a liberty interest protected by the Due Process Clause," and acknowledged the child's claim that she too had a "liberty interest" in that relationship (p. 151). Most recently, Justice Stevens, dissenting in Troxel v. Granville, reiterated that "this court has not yet had occasion to elucidate the nature of a child's liberty interests in preserving established familial or family-like bonds.. ." But, he continued, "it seems to me extremely likely that, to the extent parents and families have fundamental liberty interests in preserving such intimate relationships, so, too, do children have these interests, and so, too, must their interests be balanced in the equation" (Troxel, 2000, p. 2072).

The significance of a child's bonding to only one primary caretaker was central to the classic "psychological parent" model promulgated by Goldstein, Freud and Solnit (Goldstein et al., 1996). Their theories, which have proven so influential in federal and judicial decision making about child welfare issues, are not without critics. Some authors, for example, suggest that patterns of "multiple attachments" hold promise for children (Davis, 1996). Such an approach would bolster Justice Brennan's willingness to entertain the viability of a two-father paradigm and 
supports the more general notion that children benefit from a network of stable attachments. A modification to the single psychological parent approach, suggested by a doctor and an eminent juvenile court judge, proposes that child welfare decisions focus on what they term "reciprocal interconnectedness," considering the spectrum of relationships between children and their caregivers (Arredondo \& Edwards, 2000). Under this proposal, a court would weigh the parent's attachment to the child as well as the child's attachment to the parent, focusing on the interrelatedness between the particular child and his or her various caregivers.

I have argued in a variety of other contexts that children may have liberty interests independent of their parents, and that the law should take the young person's expression of those interests seriously (Ross, 1996, 1999a, b). Applied to ASFA, this argument suggests that where child and parent each assert a complementary independent liberty interest in preserving the parent-child relationship, the court should weigh the child's argument heavily. Despite its intended focus on the child, ASFA, as currently designed, does not afford courts the opportunity to take the individual child's views into account. Allowing a child's views to be heard does not mean that the child's preferences will trump all other arguments. Among other things, even seriously abused children frequently have strong feelings of attachment to their abusers, and the child's safety must remain paramount.

Existing sibling relationships may be a factor in the resistance some older children mount to adoption because termination of parental rights also terminates the legal relationship between siblings who may be placed separately. Many children in foster care have indicated that one of the most painful parts of their expenence was the loss of siblings (Ross, 1999a, b). When one sibling is adopted, and others remain in foster care, they often lose touch with each other completely. Termination also severs ties with other blood relatives including grandparents, aunts, and uncles, with whom the child may have a beneficial relationship of long standing.

Some young people are sophisticated enough to fight to retain important family ties. One 14-year-old resisted an adoptive placement that involved moving out of a foster home in which he had resided for eight years. He insisted that his younger sister needed him and talked about setting up a household in which he and his sister could live together. He fantasized that if the parental rights of his severely neglectful and detached mother were terminated, he would claim custody of his sister from wherever she had been placed when he graduated from the system at age eighteen. Responding to the state's notion that he could no longer linger in the legal limbo of foster care for the four years that remained of his minority, he stated simply, "the law is retarded." He may have been too harsh. But in this instance perhaps the law may be described as "doctrinally challenged."

The complexity of parental termination cases may not be amenable to the attractive simplicity of a timeline or any other mechanistic solution. It may not be possible to respond categorically to the needs of all vulnerable children. The application of general principles to specific cases may be more likely to lead to 
sensitive decisions about each neglected child. This approach would not require us to throw out the ASFA reforms, but rather would call for continued tinkering. The ultimate goal should be to replace blanket presumptions - whether they favor parents, as in the old regime, or children, as in the ASFA regime - with nuanced appraisals of individual relationships that enable judges to respond to the individual child who is, under ASFA, the proper focus of any termination proceeding.

\section{CONCLUSION}

Termination and permanency call upon decision makers to exercise delicate judgments in which they take cognizance of two competing visions of the rights of children: the right of each individual child to be nurtured, and the autonomy rights of the each child, which will not always support the same result. In the child welfare context, children clearly have a right to be protected and cared for, if not by their parents, then through the state's intervention. As much as children need to be taken care of, simple substitution of one paternalistic presence (the state) for another (the biological parent) may not be sufficiently responsive to children's claims. Just as ASFA recognizes that children's interests may diverge from those of their parents, so too may the interests of children diverge from the presumptions enunciated by the state. From the perspective of rights theory, children often have both a procedural and substantive interest in preserving family relationships that benefit them and an equally strong claim to be legally free to join a new family where the facts warrant it.

If we lived in a world where no child was ever removed unnecessarily, every child who was removed returned home as soon as basic safety could be assured, and well-designed services were available to all who needed them, then a sound legal ground for termination would generally exist after the passage of 15 months. In such a hypothetical world, one whose existence ASFA presumes, the state would be able to demonstrate the grounds for termination by clear and convincing evidence without relying on the mere passage of time. In this hypothetical universe, by the time the state filed for termination of parental rights the claims of mother and child would usually be at odds just as ASFA presumes them to be.

In the messier world that mothers and children actually inhabit, cases at the margins elude easy solutions. These marginal cases raise two separate and equally important legal problems. First, the mother's constitutional interests in her relationship with her child require that the state establish clear individualized grounds for termination. The passage of time, without more, does not appear to satisfy the heavy burden imposed on the state. Second, the child in any individual case may be better off retaining a legal relationship with her mother. Thus, the court considering a petition for termination should be required to hear any arguments a child offers for preserving the relationship and should have discretion to take those arguments into 
account. Both of these issues may be addressed if courts are required to assess the likelihood that an individual parent will be a fit or unfit parent for the individual child in the near future, rather than relying solely on a categorical 15-month rule.

The irrebuttable presumption embedded in ASFA's 15/22 month rule fails to do justice to every mother and every child that appear in a termination proceeding. The rule prevents courts from considering the narratives of each individual mother and child and of their unique relationship. It ignores context in favor of a bright line rule. In accounting for a child's sense of time and need for continuity, the resolution of each child's case requires consideration of the individual child's unique strengths, vulnerabilities, personal history and desires. The law, a crude instrument at best, needs to endeavor to respond flexibly to the minority of cases in which an individual child would be better off returning to his or her mother even after the passage of time.

The lack of clear legal grounds for termination under the $15 / 22$ months rule is the elephant in the room that no one wants to talk about. The legal grounds for termination after 15 months in foster care must be clarified, and the standards must address due process concerns. Clarification would reassure both child welfare agencies and the courts that hear their termination petitions that "permanent" decisions will withstand subsequent judicial review in the rare instances where an appeal is filed. Sensitivity to the constitutional stakes for parents is doctrinally required. A predictive approach, involving judicial scrutiny of whether a parent is likely to be able to resume safe parenting within the child's time frame, is the test least likely to violate constitutional rights. The predictive approach at its best would integrate consideration of the child's best interests with assessment of parental fault by asking whether this individual parent would be able to resume parenting responsibility for this individual child, considering the child's specific developmental needs and time frame.

Children whose circumstances diverge from ASFA's bright line approach to termination would benefit from restoration of discretion within the parameters of a rebuttable presumption that children who have been in foster care for 15 of the last 22 months should be legally free to enter a new permanent family. Such restored flexibility would enable courts to respond appropriately to individual children whose circumstances do not fit the normative model. An approach that incorporates this flexibility without giving judges unlimited discretion might even help both mother and child come to terms with the court's decision regardless of who "wins" and who "loses" in any given termination proceeding. A clear nexus between the passage of time and a constitutionally sufficient showing of parental fault would help to insure that the relationship between mother and child is not terminated needlessly in cases where their interests converge, and would also enable courts to take into account the unique child's point of view, rather than the viewpoint the state imputes to all similarly situated children. 


\section{NOTES}

1. A prima facie case is one that "on the face of it" permits a presumption that a fact is true unless disproved by evidence to the contrary.

2. Res ipse loquitur, the thing speaks for itself, is a "doctrine providing that, in some circumstances, the mere fact of an accident's occurrence raises an inference of negligence so as to establish a prima facie case" (Garner, 1999, p. 1311).

\section{ACKNOWLEDGMENTS}

The author thanks Dean Michael Young of the George Washington University Law School for institutional support, Supama Bamerjee for research assistance, Todd Melnick for reference assistance, Kerry Dunn for help in conforming to APA style, and colleagues at the Field Center for Children's Policy, Practice and Research at the University of Pennsylvania for a lively exchange of ideas. This article draws on my earlier publication: Catherine J. Ross (2003). The $\sim$ ranny of Time: Vulnerable Children, "Bad" Mothers, and Statutory Deadlines in Parental Termination Proceedings. The Virginia Journal of Social Policy \& the Law,]], 176.

\section{REFERENCES}

Acoca, L., \& Raeder, M. 5. (1999). Severing family ties: The plight of nonviolent female offenders and their children. Stanford Law and Policy Review, 11, 136.

Adoption and Safe Families Act of 1997, Pub. L. No. 105-89, 111 Stat. 2115 (1997).

Adoption Assistance and Child Welfare Act of 1980, Pub. L. No. 96-272, 94 Stat. $516(1980)$.

Allard, p. (2002). Life sentences: Denying welfare benefits to women convicted on drug offenses. Washington, DC: Sentencing Project.

American Bar Association Presidential Working Group on the Unmet Legal Needs of Children and Their Families (1993). America's Children at Risk, 50.

Anderson, M. J. (2003). Marital immunity, intimate relationships, and improper inferences: A new law on sexual offenses by intimates. Hastings Law Journal, 54, 1477-1485.

Arredondo, D. E., \& Edwards, L. P. (2000). Attachment, bonding, and reciprocal connectedness:

Limitations of attachment theory in the juvenile and family court. Journal of the Center for Families, Children \& Courts, 2, 109.

Ashe, M., \& Cahn, N. R. (1993). Child abuse: A problem of feminist theory. Texas Journal of Women and Law, 2, 76.

Bartholet, E. (1999). Nobody's children: Abuse and neglect, foster care drift, and the adoption alternative. Boston: Beacon Press.

Becker, M. E. (1995). Double binds facing mothers in abusive families: Social 
support systems, custody outcomes, and liability for acts of others.

University of Chicago Law School Roundtable, 2, 13.

Bowiby, J. (1969a). Attachment: Attachment. New York: Basic Books.

Bowlby, J. (1969b). Attachment and loss. New York: Basic Books.

Brown v. Division of Family Services, 803 A.2d 948 (Del. 2002).

Cahn, N. (2003). Battered women, child maltreatment, prison and poverty: Issues for theory and practice. American University Journal of Gende, Social Policy and the Law, 11, 359.

Chamallas, M. (2003). Introduction to feminist legal theory. Gaithersburg, MD: Aspen Law \& Business.

Coon, Gen. Stat. §17a-1 12 (2003).

Davis, P. C. (1996). The good mother: A new look at psychological parent theory. New York University Review of Law and Social Change, 22, 347.

DeBoer v. DeBoer, 509 U.S. 1301 (1993).

Denzin, N. K. (1987). Treating alcoholism: An alcoholics anonymous approach. Newbury Park, CA:

Sage.

Downey, M. (2001). Losing more than time: Incarcerated mothers and the Adoption and Safe Families Act of 1997. Buffalo Women's Law Journal, 9, 41,45.

Drinane, M. (2000). Foster care and adoption reform legislation: Implementing the Adoption and Safe Families Act of 1997. St. John's Journal of Legal Commentary, 14,444.

Duchesne v. Sugarman, 566 F.2d 817 (2d Cir. 1977).

Duquette, D., \& Hardin, M. (1999, June). Guidelines for public policy and state legislation governing permanence for children. Department of Health and Human Services.

Edelson, J. (1999). Children's witnessing of adult domestic violence. Journal of Interpersonal Violence, 14, 839.

Egami, Y. (1996). Psychiatric profile and sociodemographic characteristics of adults who report physically abusing of neglecting children. American Journal of Psychiatry, 153(7), $926-927$.

Fields, 1. (2001, April). Living arrangements of children. In: Current Population Reports. U.S. Census Bureau.

Fields, J., \& Casper, L. M. (2001, June). America's families and living arrangements. In: Current Population Reports. U.S. Census Bureau.

Fineman, M. A. (1995). The neutered mothe, the sexual family and other twentieth century tragedies. New York: Routledge.

Fineman, M. A. (1998). The inevitability of dependency and the politics of subsidy. Stanford Law and Policy Review, 9,90-91.

Freitag, R., \& Wordes, M. (2001). Improved decision making in child maltreatment cases. Journal of the Center for Families, Children and the Courts, 3, 75.

Friedland, P. (2000). Children and mothers at risk: A system failing to alleviate the devastation of drug abuse. Southern California Interdisciplinary Law Journal, 10, 124-126.

Garner, B. A. (Ed.) (1999). Black's law dictionary. St. Paul, MN: West Group.

Gelles, R. J., \& Schwartz, I. (1999). Children and the child welfare system. University of Pennsylvania Journal of Constitutional Law 296.

Gendell, S. J. (2001). In search of permanency: A reflection on the first 3 years of the Adoption and Safe Families Act implementation. Family Court Review, 39(1), 27-29. 
Gerbasi, J. B., Bonnie, R., \& Binder, R. L. (2000). Resource document on mandatory outpatient treatment. Journal of American Academy of Psychiatry and the Law, 28, 142.

Gische, J. (2000). Domestic violence as a factor in custody determinations in New York state. Fordham Urban Law Journal, 27, 937.

Goldstein, J., Solnit, A. J., Goldstein, S., \& Freud, A. (1996). In the best interest oJ (lie child: The least detrimental alernahve. New York: Free Press.

Gordon, R. (1999). Drifting through Byzantium: The promise and failure of the Adoptions and Safe Families Act. Mi,inesoa Law Review, 83, 649.

Guggenheim, M. (1995). The effects of recent trends to accelerate the termination of parental rights of children in foster care - an empirical analysis in two states. Family Law Quarterly, 29, 136.

H. R. Rep. No. 105-77 (1997), reprinted in 1997 U.S.C.C.A.N. 2739, 2740.

In Infrrest of P 0. M., 255 Ga. App. 534, 566 S.E.2d 334 (Ga. Ct. App. 2002).

In re Dependency of $J$. $W$ v. Williams, 90 Wash. App. 417, 953 P.2d 104 (Wash. Ct. App. 1998).

In re H. G., 757 N.E.2d 864 (Ill. 2001).

In re Interest of Brei'tany M. et al. v. Brett W, 11 Neb. App. 104, 644 N.W.2d 574 (Neb. Ct. App. 2002).

In re K. R., 128 Wash.2d 129, 904 P.2d 1132 (Wash. 1995).

In re Petition of Doe, 159 Ill.2d 347, 638 N.E.2d 181 (111. 1994), cert. denied, 115 S. Ct. 499 (1994).

In re R. P., M. P. and G. P., 498 N.W.2d 364 (S.D. 1993).

In re Welfare of M. H., 595 N.W.2d 223 (Mion. Ct. App. 1999).

In the Matter of I. L. N., 55 P.3d 955 (2002).

Johnson v. Arkansas Dept of Human Services, 78 Ark. App. 112, 82 S.W.3d 183

(Ark. Ct. App. 2002).

Kaufman, L. (2004, January 20). Want children back? Get a bigger apartment; A catch-22 tbr parents trying to do better. New York Times, p. B-i.

Kintzel, 5. (2002). The effects of domestic violence on welfare reform: An assessment of the Personal Responsibility and Work Opportunity Reconciliation Act as applied to battered women. University of Kansas Law Review, 50, 593-602.

Lassii'er v. Dept of Social Services, 452 U.S. 18(1981).

Lemon, N. K. D. (1999). The legal system's response to children exposed to domestic violence. Future of Children, 9, 71.

Meyer, D. D. (1999). Family ties: Solving the constitutional dilemma of the faultless father. Arizona Law Review, 41, 785-786.

Michael H. v. Gerald D.,491 U.S. 110(1989).

Mino. Stat. §260C (2003).

Minow, M. (1990). Words and the door to the land of change: Law, language, and family violence. Vanderbilt Law Review, 43, 1682-1683.

M.L. B. v. S. L J., 519 U.S. 102 (1996).

Mont. Code Ann. §41-3-604 (2001).

Mumola, C. 1. (2000, August). Incarcerated parents and their children. Bureau of Justice Statistics Special Report NCJ 182335,4.

Murphy, J. C. (1998). Legal images of motherhood: Conflicting definitions from welfare "reform," family, and criminal law. Cornell Law Review, 83, 688. 
Nicholson v. Scoppetta, 344 F.3d 154 (2d Cir. 2003).

Nicholson v. Williams, 202 F. R. D. 377, 380 (E.D.N.Y. 2001).

Nicholson ' Williams, 203 F. Supp. 2d 153 (E.D.N.Y. 2002).

143 Cong. Rec. H2017 (daily ed. Apr. 30, 1997 (statement of Rep. Hoyer).

Quilloin v. Walcott, 434 U.S. 246 (1978).

Ramsey, S. H. (2003). Children in poverty: Reconciling children's interests with child protective services and welfare policies: A response to Ward Doran and Dorothy Roberts. Maryland Law Review, 61, 441-442.

Recodo v. State, 930 P.2d 1128 (Nev. 1997).

Roberts, D. (2002). Shattered bonds: The color of child welfare. New York: Basic Books.

Ross, C. J. (1996). From vulnerability to voice: Appointing counsel for children in civil litigation. Fordham Law Review, 64, 1571, 1579-1586.

Ross, C. J. (1999a). An emerging right for mature minors to receive information. University of Pennsylvania Journal of Constitutional Law, 2, 223.

Ross, C. J. (1999b). Families without paradigms: Child poverty and out-of-home placement in historical perspective. Ohio State Law Journal, 60, 1256$1261,1290-1292$.

Ross, C. J. (2000). Anything goes: Examining the state's interest in protecting children from controversial speech. Vanderbilt Law Review, 53, 463-467.

Ross, C. J., \& Cahn, N. R. (2000). Subsidy for caretaking in families: Lessons from foster care. American University Journal of Gender Social Policy and the Law, 8, 70.

Santosky v. Kramer, 455 U.S. 745 (1982).

S. C. Code. Ann. §20-7-1572 (West 2003).

750 Ill. Comp. Stat. 50/1(D)(m-1) (West 1998).

Singer, J. W. (2001). Introduction to property. Gaithersburg, MD: Aspen Law \& Business.

Smart, C. (1989). Feminism and the power of law. London: Routledge.

Smith v. Organization of Foster Families for Equality and Reform, 431 U.S. 816

(1977).

Stanley v. Illinois, 405 U.S. 645 (1972).

State Department of Human Resources v. A. K., 851 So.2d 1 (2002), cert. Denied, 851 So.2d 23 (Ala. Nov. 27, 2002).

Strengthening Abuse and Neglect Courts Act of 2000, Pub. L. No. 106-3 14, 114 Stat. 1266 (2000).

Tenenbaum v. Willams, 193 F.3d 581 (2d Cir. 1999).

The National Center on Addiction and Substance Abuse at Columbia University (1999). No safe haven: Children of substance abusing parents. New York:

National Center on Addiction and Substance Abuse at Columbia University.

Troxel v. Granville, 530 U.S. 57 (2000).

United States Department of Health and Human Services (1999, April). Blending perspectives and building common ground: A report to Congress on substance abuse and child protection. Washington, DC: United States Department of Health and Human Services.

United States General Accounting Office (1998, September). Foster care: Agencies facing challenges securing stable homes for children of substance abusers. GAO/HEH-98-182, 2.

United States General Accounting Office (1999, December 22). State's early experiences implementing the adoption and safe families act. GAO/HEHS- 
$00-J, 6$.

United States General Accounting Office (2002, June). Foster care: Recent legislation helps states focus on finding permanent homes for children, but long-standing barriers remain. GAO-02 -585, $23-31$.

Utah Code Ann. §78-4a-311 (2003).

Venier, R. (2000). Parental rights and the best interests of the child: Implications of the Adoption and Safe Families Act of 1997 on domestic violence victims' rights. American University Journal of Gendei Social Policy and the Law, 8, $523-529$.

Williams, J. (2000). Unbending gender: Why family and work conflict and what to do about it. Oxford:

Oxford University Press.

Woodhouse, B. B. (1993). Hatching the egg: A child-centered perspective on parents' rights. Cardozo Law Review, 14, 1809-1811.

Woodhouse, B. B. (1999). The dark side of family privacy. George Washington Law Review, 67, 1247. 